Comparative Biochemistry and Physiology -

Part A: Molecular \& Integrative Physiology

May 2007 ; Volume 147, Issue 1, Pages 205-214
Archimer, archive institutionnelle de l'Ifremer http://www.ifremer.fr/docelec/

\title{
Effects of different dietary levels of fish protein hydrolysates on growth, digestive enzymes, gut microbiota, and resistance to Vibrio anguillarum in European sea bass (Dicentrarchus labrax) larvae
}

\author{
Y. P. Kotzamanis ${ }^{a, *}$, E. Gisbert ${ }^{b}$, F.J. Gatesoupe ${ }^{c}$, J. Zambonino Infante ${ }^{c}$, C. Cahu ${ }^{c}$
}

\begin{abstract}
${ }^{2}$ Hellenic Centre for Marine Research, Institute of Aquaculture, Agios Kosmas, Hellinikon 16610, Athens, Greece.

'b IRTA, Centre d'Aqüicultura, Crta. De Poblenou s/n, 43450 Sant Carles de la Ràpita, Tarragona, Spain

'INRA-Ifremer, UMR Nutrition Aquaculture et Génomique, Centre de Brest, BP 70, 29280 Plouzané, France
\end{abstract}

\author{
*: Corresponding author: Tel.: +30-210-98 56 734; fax: +30-210-98 11713. \\ E-mail: jokotz@ath.hcmr.gr (Y.P. Kotzamanis).
}

\begin{abstract}
:
Two Fish Protein Hydrolysates (FPH) were incorporated into four diets prepared for start-feeding sea bass larvae, at two different levels (10\% and $19 \%$ of total ingredients): a commercial FPH, CPSP, in which the molecular weight of the main fraction of soluble peptides (51\%) was between $500-2500 \mathrm{Da}$, and an experimental FPH obtained by acidic silage of sardine offal, $\mathrm{SH}$, with a main portion of soluble peptides (54\%) ranging from 200 to $500 \mathrm{Da}$. The diet with $10 \%$ of the commercial FPH gave the best results in terms of growth, survival and intestinal development, as evaluated by the early activity of digestive enzymes in the brush border membrane (alkaline phosphatase and aminopeptidase $\mathrm{N}$ ). This was related to the low level of Vibrio spp. counted in the larvae of group C10. The high dose of FPH, especially in the experimental preparation rich in short peptides, seemed to favour the dominance of Vibrio sp. TYH3, which behaved opportunistically. The effect of the experimental FPH was ambiguous, since early larvae challenged with Vibrio anguillarum were more resistant to the pathogen, especially at high FPH dose (group S19). This might be due either to direct antagonism between $V$. anguillarum and Vibrio sp. TYH3, or to the stimulation of the immune response in the larvae. These results indicate that different molecular weight fractions and concentrations of feed-soluble peptides may affect the growth performance and immunological status of sea bass larvae. Consequently, a low dose of commercial FPH seems advisable, both for larval development and for the bacterial environment, although further research is required to determine and characterize peptide fractions that may have a beneficial effect on growth and immune response, and to determine their optimal inclusion levels in diets for sea bass larvae.
\end{abstract}

Keywords: Fish larvae; development; digestive enzymes; fish hydrolysate; bacterial challenge microbiota; Vibrio, Marinomonas; Bacillus; Pseudoalteromonas 


\section{Introduction}

Fish protein hydrolysates (FPH) have been used as substitutes for fish meal in aquaculture feeds in order to enhance the growth and survival of marine fish (Hardy, 1991). Several studies have investigated the effects of dietary hydrolysed protein on the growth of Atlantic salmon (Salmo salar- Lall, 1991; Parrish et al., 1991; Heras et al., 1994; Berge and Storebakken, 1996), rainbow trout (Oncorhynchus mykissAksnes et al., 2006), goldfish (Carassius auratus- Szlaminska et al., 1991), tilapia (Oreochromis niloticus- Lapie and Biqueras-Betinez, 1992; Fagbenro et al., 1994), carp larvae (Cyprinus carpio- Carvalho et al., 1997), and Japanese sea bass (Lateolabrax japonicus- Liang et al., 2006). None of the preview works provided any information either on the degree of hydrolysis associated with dietary FPH or on the molecular weight profile of the soluble peptides produced during hydrolysis. The degree of protein hydrolysis affects certain product properties, like viscosity, solubility and the partition of proteins. These, in turn, influence the absorption capacity and rate of passage of the diet through the gastrointestinal tract (Espe et al., 1999). The solubility of FPH depends on the raw material, proteolytic method, temperature, and processing time (Raa and Gildberg, 1982; Fagbenro et al., 1994; Espe and Lied, 1999).

Day et al. (1997) found that survival was improved in juvenile Dover sole (Solea solea) fed on a diet in which the protein was totally replaced by a hydrolysate. Espe et al. (1999) reported that the replacement of less than $15 \%$ of fishmeal by acidic silage improved the growth of juvenile and adult Atlantic salmon. Refstie et al. (2004) found that the dietary substitution of $10 \%$ to $15 \%$ of fish meal by a commercial enzymatically- treated FPH positively affected the growth performance of Atlantic salmon. More recently, Liang et al. (2006) reported that the dietary addition of $15 \%$ FPH prepared from pollock by-products supported higher growth in Japanese sea bass compared with higher and lower inclusion levels.

The incorporation of FPH in artificial larval diets has been suggested as an alternative approach for overcoming the limited digestive capacity of fish larvae (Dabrowska et al., 1979; Dabrowski, 1984; Govoni et al., 1986). Zambonino et al. (1997) initially indicated that the best incorporation rate for a FPH rich in di-peptides and tri-peptides was $20 \%$ of the total nitrogen supply, since such a diet improved the growth and survival of sea bass larvae, compared with groups fed on diets without FPH, or at a replacement rate of $40 \%$. A similar trend was observed by Cahu et al. (1999), who found that replacing 25\% of fish meal with a commercial FPH facilitated the onset of the adult mode of digestion in developing sea bass larvae, while replacement rates of $50 \%$ and $75 \%$ led to a reduction in larval growth. Carvalho et al. (2004) documented the importance of the solubility and peptide profile of casein hydrolysates in the diets of common carp larvae. The beneficial effect of pre-hydrolysis on the utilization of dietary protein was also reported in Atlantic halibut (Hyppoglossus hyppoglossus) larvae (Tonheim et al., 2005).

In addition to the benefits in growth performance, it has been shown that fractions of peptides derived from hydrolysated muscle and the empty stomachs of cod stimulated the activity of Atlantic salmon head kidney leucocytes (Bøgwald et al., 1996; Gildberg et al., 1996). However, Murray et al. (2003) did not find any positive effect of the dietary protein hydrolysate on the innate immune functions of juvenile coho salmon. 
The introduction of dietary FPH may also affect microbiota, as they can boost bacterial proliferation. It is particularly important to monitor intestinal microbiota to make sure that they are not detrimental in this respect. In larval stages, fish mortality can be high due to opportunistic pathogens, and the early weaning of larvae with compound diets may cause bacterial growth, especially that of Vibrio species (Gatesoupe et al., 1997). Severe and moderate mortalities caused by outbreaks of vibriosis outbreak have been respectively reported in sea bream and sea bass larvae (Grisez et al., 1997).

The optimum combination of dose and proteolysis level of FPH in the weaning diets of sea bass larvae has not been established yet. The aim of this study was to investigate the effects of two dietary levels of experimental acidic silage FPH, on the growth performance, survival, digestive enzymes and gut microbiota of European sea bass larvae, which were also challenged with Vibrio anguillarum and compared to a commercial enzymatic hydrolysate with a different solubility and peptides profile.

\section{Materials and methods}

\subsection{Preparation of sardine hydrolysate (SH)}

By-products of sardine were derived from a canning line at a fish processing plant (North Aegean Sea Canneries S.A., Kilkis, Greece). They mainly consisted of sardine heads with and a small percentage of whole sardines (Sardina pilchardus). The offal was transferred to a deep-freeze immediately after processing and stored at $-20{ }^{0} \mathrm{C}$. Silage was prepared from minced sardine offal by adding $22 \mathrm{~g} \mathrm{~kg}^{-1}$ (v/w) formic acid (85\%). It was then stored at $25 \pm 1{ }^{\circ} \mathrm{C}$ for 5 days, stirring periodically. Afterwards it was heated in an oven at $90{ }^{\circ} \mathrm{C}$ for about 10 minutes before freeze-drying.

\subsection{Experimental diets and larval rearing}

Four compound diets were formulated (Table 1). In diets S19 and C19, the protein hydrolysate - consisting of sardine silage ( $\mathrm{SH}, 42 \%$ crude protein) and a commercial enzymatic FPH (CPSP, Concentré Protéique soluble de Poisson, Sopropêche, Boulogne-sur-Mer, France, 82\% crude protein), respectively - was incorporated at a level of $19 \%$. The remaining of the dietary protein fraction was supplied by fishmeal (Norse LT 94). The diet with 19\% CPSP (C19) corresponded to the one that gave the best results when tested by Cahu et al. (1999), and was used as a control. In diets S10 and C10, replacement of fishmeal with sardine silage or CPSP was limited to $10 \%$. The ingredients were mixed with water, pelletized and dried at $60{ }^{\circ} \mathrm{C}$ for $25 \mathrm{~min}$. The pellets were then sieved to obtain a particle size of 200-400 $\mu \mathrm{m}$.

European sea bass larvae (Dicentrarchus labrax) were obtained from the Aquanord marine farm (Gravelines, France). They were reared at IFREMER facilities, Centre de Brest, in running seawater. Larvae were randomly distributed among 12 conical fiberglass tanks (35 l) at 4 days post-hatching (dph), with an initial stocking density of 60 larvae $\mathrm{l}^{-1}$. Water temperature was $20^{\circ} \mathrm{C}$ and the physical rearing conditions were as previously described (Cahu and Zambonino Infante, 1994). Mouth opening occurred at $5 \mathrm{dph}$ and the larvae were kept in the dark without food until $7 \mathrm{dph}$. During this period, larvae had exclusively an endogenous feeding. The 4 experimental diets were 
given from day 8 dph onwards. Three replicates were used for each diet. In parallel, larvae from the same batch were allotted to 4 conical fiberglass tanks (100 l), with the same stocking density, and fed the experimental diets before being used in a challenge trial at $16 \mathrm{dph}$. Fish were fed to excess $18 \mathrm{~h} /$ day, using belt feeders. The experiment continued until $33 \mathrm{dph}$.

\subsection{Analytical methods}

Protein solubilities in sardine and CPSP hydrolysates were determined by the trinitrobenzosulphonic acid (TNBS) method (Adler-Nissen, 1979) and the degree of hydrolysis was calculated as a proportion (\%) of free a-amino groups with respect to total a-amino groups in each sample. Analyses were performed in duplicate. The molecular weights of soluble protein fractions in sardine and CPSP hydrolysates were determined, with slight modifications, according to Boza et al., (1994). Briefly stated, aliquots of each sample were dissolved in $0.07 \mathrm{M}$ phosphate buffer $\left(10 \mathrm{mg} \mathrm{ml}^{-1}\right)$ at $\mathrm{pH}$ 8.0, homogenized, stirred for $10 \mathrm{~min}$ on a magnetic plate and centrifuged at 3,000 rpm for $10 \mathrm{~min}$. The supernatants were filtered through a $0.2 \mu \mathrm{m}$ pore filter and analyzed by HPLC-gel filtration chromatography in an ALLIANCE $2690^{\mathrm{MX}}$ (Waters, MA, USA) system equipped with a TSK-Gel G2000SW XL $_{\text {column (TOSOH }}$ BIOSCIENCE, Stuttgart, Germany) and 2996 Photodiode Array Detector (Waters, MA, USA). The mobile phase was $0.1 \mathrm{M}$ sodium sulphate in phosphate buffer $0.07 \mathrm{M}$ at a flow rate of $1 \mathrm{ml} \mathrm{min}^{-1}$. Column effluent was monitored for UV light absorption at $230 \mathrm{~nm}$. Peak identification and integration was performed by the software Millennium $^{32}$ Chromatography Manager (Waters, MA, USA). The molecular weights of the protein fractions were calculated with reference to the retention times of the following molecular weight standards: bovine albumin (67000 Da; Sigma A-4503), ribonuclease A (13000 Da; Sigma R-5250), insulin chain A (2532 Da; Sigma I-1633), Tyr-Tyr-Tyr (508 Da; Sigma T-2007) Val-Tyr-Val (379 Da; Sigma V-8376), Ltryptophan (204 Da; Sigma T-0254), and DL- phenylalanine (165 Da; Sigma P 4905). Based on their respective retention times and according to International Union of Pure and Applied Chemistry (IUPAC) peptide nomenclature, four molecular weight soluble fractions were defined: $<200$ Da (corresponding mainly to free amino acids), 200-500 Da (corresponding mainly to di-and tripeptides), 500-2500 Da (corresponding mainly to oligopeptides), and $>2500$ Da (corresponding mainly to polypeptides).

The chemical composition of the ingredients and diets were determined according to standard procedures: dry matter by drying in an oven at $105{ }^{0} \mathrm{C}$ for $24 \mathrm{~h}$, ash by combustion at $550{ }^{\circ} \mathrm{C}$ in a muffle furnace for $24 \mathrm{~h}$, nitrogen by the Dumas combustion method (A.O.A.C. 990.03) and lipids according to Folch et al. (1957).

\subsection{Sampling and dissection}

Thirty larvae per dietary group were sampled using a nest after lowering the water column at days $8,15,22,29$ and 33 for growth monitoring. This procedure allowed a fast sampling without stress for larvae. At the end of the experimental period, the survival of larvae was determined by counting the population in each tank. On days 26 and 33, 50 larvae per tank were collected for enzymatic measurements before administering the daily food supply. They were immediately frozen and stored at - 
$80^{\circ} \mathrm{C}$. The larvae were dissected and their pancreatic and intestinal segments were separated according to Cahu and Zambonino Infante (1994).

\subsection{Enzymatic assays}

The dissected segments were homogenized in five volumes $(\mathrm{v} / \mathrm{w})$ of distilled cold water $\left(4^{\circ} \mathrm{C}\right)$. Amylase and trypsin were assayed according to Métais and Bieth (1968) and Holm et al. (1988), respectively. Brush Border Membranes (BBM) were purified from the intestinal segment homogenate according to the modified method of Zambonino Infante et al. (1997) for intestinal scraping (Crane et al., 1979). BBM enzymes, Aminopeptidase N (AN) and Alkaline Phosphatase (AP) were measured according to Maroux et al. (1973) and Bessey et al. (1946), respectively. Enzyme activity was expressed as segmental activity in $\mathrm{mU}$ (intestinal segment $)^{-1}$. The secretion of trypsin and amylase was expressed as a ratio of their segmental activity in the intestinal segment with respect to the total activity assayed in both pancreatic and intestinal segments (Cahu et al., 1999). Protein content was determined by the Bradford method (Bradford, 1976).

\subsection{Microbiological methods}

At 17 and 26 dph, 20 larvae from each rearing tank were sampled before the daily food distribution to count bacteria, according to the methods previously described (Gatesoupe, 1995). Under sterile conditions, larvae were rinsed over a $450 \mu \mathrm{m}$ net, resuspended in $4.5 \mathrm{ml}$ of half-strength seawater, and crushed in a glass homogeniser. After homogenisation, appropriate dilutions were spread on Petrifilm (Aerobic Count Plates, 3M Microbiology products) and TCBS (thiosulfate-citrate-bile-salt agar, AES Laboratoire, dissolved in half-strength seawater), for rough estimation of Vibrio spp. counts. The plates were incubated at $20^{\circ} \mathrm{C}$ and inspected for up to 5 days. The detection level was 20 colony-forming units (CFU) per larva. At least 10 colonies were sampled on each individual Petrifilm for further biochemical identification. The selected isolates were cultivated on Plate Count Agar (PCA, AES Laboratoire, enriched with $18 \mathrm{~g} \mathrm{l}-1 \mathrm{NaCl}, \mathrm{pH}$ adjusted to 7.8). The phenotypic characterisation of the isolates was determined with API 20 E strips according to manufacturer's instructions (bioMérieux). It has been reported that API 20E is the most commonly used kit for rapid diagnosis of bacteria from fish (Popovic et al., 2004). API $20 \mathrm{E}$ profiles were compared using the Wagner parsimony method, using Mix of Phylip (Felsenstein, 1996), to arrange the strains in dendrograms drawn with Fixdtree (Felsenstein, 1996) in order of similarity. Then DNA was extracted and the fragments corresponding to 16S rDNA were amplified by PCR. The isolates were clustered according to their genotypic similarity, characterized by Amplified Ribosomal DnaRestriction Analysis (ARDRA) of the PCR products using Hae III and Cfo I (Gatesoupe, 2002). One isolate per dominant cluster was selected for sequencing the 16S rDNA gene (partial sequences of 570 - 923 bp from primer SA-dir 5'agagtttgatcatggctcag-3'). The phylogenic position of the cluster was then searched with BLAST (NCBI). 


\subsection{Challenge trial}

At 16 dph, 50 larvae from 6 different tanks corresponding to each experimental diet were transferred before the daily food supply into $500 \mathrm{ml}$ bottles with screw closure. The larvae were challenged with a strain of Vibrio anguillarum, pathogenic to sea bass larvae. According to the method of Gatesoupe (1995), the initial concentration of the bacterial inoculum and the duration of the test were preset to obtain the mortality peak in a short time, not long enough to affect survival in the control group without infection. Approximately $10^{9} \mathrm{CFU}$ were added to each challenge bottle to obtain $2 \times$

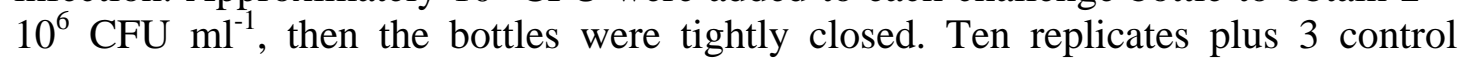
replicates without the pathogen were prepared for each dietary group. The challenge experiment lasted 4 days and mortality was calculated by counting the survivors.

\subsection{Statistical analysis}

Student's t test was used to compare the mean differences in solubility and peptide weights after arcsine square root transformation. Data on survival, trypsin and amylase secretion levels were also arcsine square root transformed. The normality and homogeneity of the data were checked with the tests of Kolmogorov-Smirnov and Bartlett, respectively. Data were compared by the analysis of variance (ANOVA) at the 0.05 significance level. Significant differences in mean weights were revealed by Tukey's test. Due to the large number of measurements, this test was selected instead of the Newman-Keuls test, which can potentially identify falsely significant differences (Zar, 1996). The data with few replications for the enzyme assays challenge test and the bacterial counts were analysed by applying the Least Significant Difference (LSD) test, which is less conservative than Tukey's test. The bacterial counts were log transformed, then analysed in a three-way ANOVA. Data from the challenge test were analysed with one- and two-way ANOVA, after arcsine square root transformation.

\section{Results}

\subsection{Protein solubility and peptide profile of the dietary hydrolysates}

Significant differences were revealed between the two types of dietary hydrolysates with respect to the solubility and molecular weight distribution of the solubilised protein (Table 2). CPSP hydrolysates showed a higher degree of hydrolysis (DH) compared with $\mathrm{SH}$ (61.4\% and $46.5 \%$, respectively) and thereby higher protein solubility since DH is positively correlated to the solubility of the FPH.

The chromatographic peptide profiles of the two types of dietary hydrolysates are shown in Fig. 1. The main fraction of soluble peptides of CPSP hydrolysates (51.4\%) was constituted by oligopeptides with more than three residues (500-2500 Da) followed by di-/tripeptides (36.5\%), proteins/polypeptides (10.6\%) and free amino acids (1.5\%) (Table 2). On the other hand, SH hydrolysates contained a high proportion (54\%) of di-/tripeptides (200-500 Da) and free amino acids (4.3\%) and fewer oligopeptides (35\%) or proteins/polypeptides (6.5\%) compared with CPSP hydrolysates. 


\subsection{Larval growth, survival and enzymes activity}

At the end of the trial (33 dph), no significant differences were found between survival rates for the different dietary groups, which were $38 \pm 5,36 \pm 7,43 \pm 4$, and $33 \pm 7 \%$ for groups C19, S19, C10, and S10, respectively.

Differences in growth between groups were already obtained from 15 dph (Fig. 2), when a significantly higher mean weight was observed with low levels of FPH, regardless of the type of hydrolysate (groups C10 and S10). Larvae fed on the C10 diet presented the highest growth performance from $22 \mathrm{dph}$ until the end of the trial and exhibited significantly higher final wet weight than larvae fed on the S10 diet with the same level but a different type of hydrolysates (Fig 2).

There was no significant difference in growth between the two groups fed on the diets with high levels of FPH (C19 and S19) throughout the experimental period.

Rates of trypsin and amylase secretion were not significantly different at 26 and 33 dph (Table 3). However at 33 dph, trypsin secretion with diet S19 tended to be lower than that observed with the other diets (39 vs. $52-58 \%, P=0.06$ ).

The segmental activities of BBM enzymes are given in Fig. 3. Both alkaline phosphatase and aminopeptidase activity presented the same pattern; increasing from day 26 to day 33. Larvae fed on the C10 diet showed significantly higher intestinal enzyme activity than those fed on the other diets. Differences with AN were not significant at $26 \mathrm{dph}$ but the trend was quite similar $(P=0.07)$.

\subsection{Bacterial assays and challenge}

No significant differences were observed between bacterial samples counted on Petrifilm and expressed in CFU per individual larva (Table 4). The three-way ANOVA indicated that the only significant differences were related to the date of sampling for TCBS counts, which were ca. $10^{2}-10^{3}$ CFU per larva at $17 \mathrm{dph}$, and less than $10^{2}$ at $26 \mathrm{dph}$. However, the lowest TCBS counts were observed in group C10 at both dates. At $17 \mathrm{dph}$, the characterization revealed that Vibrio spp. represented only $4 \%$ of the isolates in group C10, whereas they represented $27 \%$ of the isolates in group C19 (Table 5). Both dose and FPH type affected the proportion of Vibrio spp. in larval microbiota, since $32 \%$ and $52 \%$ of the isolates respectively corresponded to this genus in larvae fed on diets S10 and S19. The dominant species of Vibrio were also different, depending on the dietary FPH. Highly diversified strains of Vibrio were observed in group $\mathrm{C} 19$, where $7 \%$ of the isolates belonged to cluster TYH3, while the other 20\% characterised as Vibrio spp. corresponded each ones to different genotypes. A clear dominance of two clusters of Vibrio was observed in groups S10 and S19. The $16 \mathrm{~S}$ ribosomal RNA genes in cluster TYH3 and B4Y78 were closely related to those in Vibrio sp. RE1-3 (Patel et al., 2003) and Enterovibrio norvegicus LMG 19842 (Thompson et al., 2002), respectively. The proportion of cluster TYH3 seemed affected both by the type of FPH and the dose, whereas cluster B4Y78 was exclusively observed in larvae fed with the experimental FPH. Marinomonas spp. were dominant in the microbiota from group C10 (cluster B4N46, close to $M$. mediterranea MMB-1, Solano and Sanchez-Amat, 1999; cluster B4C03, close to $M$. primoryensis KMM 3634, Romanenko et al., 2003). Bacillus spp. were dominant in group C19 (cluster B4C54, close to Bacillus sp. 19491, Heyrman and Swings, 2001; 
cluster B4C57, close to Bacillus sp. IDA1983, Felske et al., 2003). Pseudoalteromonas sp. was observed in all groups, but to a lesser extent in group C19 (one cluster close to Pseudoalteromonas sp. SM9913, Chen, 2003). Other bacterial genotypes referred as "others" were observed once, in various proportion depending on the treatments. The greatest diversity in microbiota was noted in groups C19 and S10 (26\% and $24 \%$ of the isolates, respectively). At $26 \mathrm{dph}$, the microbiota could not be efficiently characterized due to the dominance of bacteria which were detected on Petrifilm but which did not subsequently grow on PCA plates. At this date, TCBS counts were highly variable in group S19, due to the proliferation of Vibrio sp. TYH3 in one replicate $\left(2 \times 10^{5} \mathrm{CFU}_{\text {larva }^{-1}}\right)$.

After 3 days of challenging with Vibrio anguillarum, the larvae fed on diet S19 until 16 dph presented a significantly lower mortality rate than those of groups C10 and C19 in one-way analysis (9 vs. 19-23\%, Table 6). Meanwhile, mortality was between $0 \%$ and $2 \%$ in control bottles without infection, except in one corresponding to diet S10 (5\%). Two-way analysis of variance indicated that the dose of FPH had no effect on mortality after infection, and that interaction was not significant, whereas the difference due to the type of hydrolysate was highly significant.

\section{Discussion}

A lot of attention has been given to understanding amino acid metabolism and the requirements of marine fish larvae (Plakas and Katayama, 1981; Watanabe and Kiron, 1994; Rønnestad et al., 1999; 2003; Applebaum and Rønnestad, 2004; Aragão et al., 2004). Consequently, adequate supplementation and balance of amino acids have greatly improved formulated micro-diets for replacing live prey at early larval stages. However, very little attention has focused on the appropriate peptide profile of the microdiet.

In the present study, two types of fish protein hydrolysates and two dietary inclusion levels were tested in the diets of sea bass larvae from mouth opening until day 33. The main differences between the hydrolysates related to the molecular weight distribution of their peptides and their degree of solubility, both of which originated from the different hydrolysis procedures applied. The results indicated that $\mathrm{SH}$ hydrolysates were less soluble and contained a larger proportion of short peptides, namely di/tripeptides, than CPSP hydrolysate. Amino acid analysis was not performed, since little variation was observed in the amino acid composition of either FPH or fishmeal produced from different fish species (Hertrampf and Piedad-Pascual, 2000).

The incorporation of CPSP hydrolysates (treatment C10) in the diet at a concentration of $10 \%$ effectively improved growth, survival and the intestinal development of sea bass larvae. At $15 \mathrm{dph}$, the diets with low replacement rates for fishmeal by FPH (10\% of total ingredients) produced improved growth of sea bass larvae with respect to diets with higher replacement rates of $19 \%$, such as those already tested by Cahu et al. (1999). After that day and until the end of the trial (day 33), the best growth and survival rates were obtained with the low dose of CPSP, whereas the worst was observed with the low dose of the experimental sardine hydrolysate. The fact that $\mathrm{SH}$ hydrolysate contained more than $50 \%$ of di-/tripeptides, may explain the reduction in overall larval performance. Carvalho et al. (2004) also found that a dietary excess of di- and tripeptides detrimentally affected the performance of common carp larvae in early feeding stages and hypothesized that the subsequent reduced larval performance was either due to the saturation of the peptide transport mechanism or to the rapid 
hydrolysis of low molecular weight peptides, which produced an excess of amino acids that subsequently saturated the amino acid intestinal transport mechanisms.

Both fish larvae and adult fish are capable of absorbing di- and tripeptides (Govoni et al., 1986) but there are only a limited number of intestinal peptide transporters (Bakke-McKellep et al., 2000). Saturation and competition of amino acids for transport mechanisms have been proposed as causes for the detrimental effects associated with fish fed on high levels of free amino acids (Plakas and Katayama, 1981). Rønnestad et al. (2000) suggested that the faster absorption of the free amino acids, present in excess in some diets, might lead to amino acid imbalances. In line with previous speculation, Kolkovski and Tandler (2000) assumed that a fast flow of short peptides through the gut wall might saturate the larval digestive system.

These assumptions do not contradict the findings of Zambonino Infante et al. (1997), who reported that the dietary incorporation of a fishmeal hydrolysate at a $20 \%$ level, which mainly contained di- and tripeptides (75\%) significantly improved the survival and growth of European sea bass larvae compared to a diet with $40 \%$ fishmeal hydrolysate. In that work, native-intact proteins were substituted by one type of FPH. In our study, comparisons have been performed between two types and levels of dietary hydrolysates with different peptide profiles.

Oligo-/ polypeptides and proteins (> $500 \mathrm{Da}$ ) in live feed (rotifers and Artemia), which is still considered a standard food for fish larvae, occur in more than $84 \%$ of the total molecular weight distribution whilst di-/tripeptides and amino acids account for less than $11 \%$ and $7 \%$, respectively (Carvalho et al., 2003). If peptidic profile and solubility of artificial diets for fish larvae should be similar to those of live food, CPSP hydrolysates would seem to approximate the requirements better than $\mathrm{SH}$ in terms of peptide profiles.

Findings on growth were supported by the notable effect of the low dose of CPSP on the early stimulation of the BBM digestive enzymes. Intestinal maturation in sea bass is characterized by a decrease in cytosolic digestion followed by an increase in brush border membrane enzyme activity (Cahu and Zambonino Infante, 1995). The segmental activities of BBM enzymes increased between day 26 and day 33, reflecting a normal intestinal maturation process. The elevated levels of aminopeptidase and alkaline peptidase in both 26 and 33 dph larvae fed the low dose of CPSP showed that maturation of the intestine occurred earlier in this group than in the others.

However, although the levels of trypsin and amylase secretion seemed to increase from 26 to $33 \mathrm{dph}$, they were not significantly different among the experimental groups. It can be noted that secretion levels of trypsin and amylase were similar and adequate in all groups, suggesting that the pancreatic maturational process had occurred in each group (Cahu et al., 1999). Enzymatic data indicated that the best development was induced by the diet containing 10\% CPSP. The other diets, containing higher levels of hydrolysate (19\%) or a high proportion of short peptides, led to delayed larvae development.

The immune system may also be affected by FPH supply. It should be noted that experimental acid silage significantly increased the resistance of larvae challenged with $V$. anguillarum. There have been reports of biologically active peptides with immuno-stimulating and antibacterial properties being produced during the hydrolyzing procedure (Coste et al., 1992; Bøgwald et al., 1996; Gildberg et al., 1996; Daoud et al., 2005). However, it is not known whether such biologically active peptides existed in the two types of experimental FPH tested and so further research is required in this area. 
Nevertheless, none of these effects on growth, development, digestion, and possibly, immunity should only be considered in the light of a direct relationship between nutrients and the animal. The FPH also affected microbiota, which was not surprising, given that protein hydrolysates are major ingredients in most culture media for bacteria. In spite of this effect of FPH on microbiota, it must be noted that the bacterial load in the present experiment was much lower than that previously observed $\left(10^{2}-10^{3}\right.$ vs. $10^{5}-10^{6}$ CFU larva $^{-1}$, Gatesoupe et al., 1997). This may be attributable to improvements in rearing techniques and diet composition, since FPH represented half of the amino acid supply in the previous experiment. The expression of bacterial counts per individual does not take into account larval growth, and in the present experiment mean weights were multiplied by ca. five from 17 to $26 \mathrm{dph}$. Counts on Petrifilm would therefore tend to decrease between the two sampling dates if expressed in CFU per $g$ of intestine, while TCBS counts, which provide a rough estimate of Vibrio spp., even decreased on an individual larvae basis. The proportion of Vibrio spp. was clearly related to the dose and type of FPH at $17 \mathrm{dph}$. The dominance of cluster TYH3, and possibly also that of B4Y78, may at least partially explain the increased resistance of sea bass larvae in the challenge at $16 \mathrm{dph}$. This has already been observed in turbot larvae, in which an artificial dominance of Vibrio sp. was created (Gatesoupe, 1997). Such an improvement in the resistance of the larvae might be due to a barrier effect, with settled strains preventing the pathogenic Vibrio from invading the larvae. An alternative hypothesis would be the stimulation of the immune system by the settled strains. For instance, a probiotic strain of $V$. fluvialis stimulated the immune response of rainbow trout, thus preventing furunculosis (Irianto and Austin, 2002). Nevertheless, it should be borne in mind that there is some risk of favouring the proliferation of Vibrio spp., even if the strains are reputedly safe. Cluster TYH3 showed opportunistic behaviour in one replicate at $26 \mathrm{dph}$, although no clearly detrimental effect was detected. It certainly does not seem advisable to use dietary FPH to haphazardly stimulate bacteria that are supposed to provide certain probiotic effects. Moreover, the challenge test was performed under stressful conditions that are unlikely to occur during normal rearing, where it would seem wise to try to reduce the bacterial load as much as possible. Consequently, the low dose of CPSP may be safe, even if protection against the pathogen is not optimal under extreme conditions. By the end of the first month of rearing, the dominant strains in the larval microbiota did not seem to be cultivable on plate count agar, except when there was opportunistic proliferation of Vibrio sp. This situation is different from those previously observed for larvae fed on a compound diet (Gatesoupe et al., 1997) or live food organisms (Gatesoupe, 2002). New techniques are required for further study, including direct counting by epifluorescence microscopy and randomly cloned eubacterial 16S rDNA (Hold et al., 2002).

In conclusion, the present study mainly provides evidence of the significance of the level and molecular weight distribution of peptides in compound diets for feeding newly hatched sea bass larvae. Further investigations concerning the optimal dietary peptide profile and the speculated bioactive fractions are requested in order to propose an optimal hydrolytic procedure for valorising fish by-products. The prevention of fish disease may benefit from further progress in diet formulation. For instance, it may be interesting to try combining low doses of FPH with the omission of mineral iron supply, which has been already proposed (Gatesoupe et al., 1997). 


\section{Acknowledgements}

This work was carried out within the framework of ASEFAF, and supported by the ARI Programme "improving human potential for Research" from the European Union through contract HPRI-CT-2001-00146. The authors would like to thank Mrs M. Yiagnisis for the kind donation of the $V$. anguillarum strain and Dr A. Carvalho for his support in the HPLC-gel filtration chromatography. The technical assistance of P.Quazuguel and M.M. Le Gall was highly appreciated throughout the study. Torril Berg of NIFES is thanked for the TNBS analysis.

\section{References}

Adler-Nissen, J., 1979. Determination of the degree of hydrolysis of food protein hydrolysates by trinitrobenzenesulfonic acid. J. Agric. Food Chem. 27, 12561262.

Aksnes, A., Hope, B. Jönsson, E., Björnsson, B.T., Albrektsen, S., 2006. Sizefractionated fish hydrolysate as feed ingredient for rainbow trout (Oncorhynchus mykiss) fed high plant protein diets. I: Growth, growth regulation and feed utilization. Aquaculture 261, 305-317.

Applebaum, S.L., Rønnestad, I., 2004. Absorption, assimilation, and catabolism of individual free amino acids by larval Atlantic halibut (Hippoglossus hippoglossus). Aquaculture 230, 313-322.

Aragão, C., Conceição, L.E.C, Martins, D., Rønnestad, I., Gomes, E., Dinis, M.T., 2004. A balanced dietary amino acid profile improves amino acid retention in post-larval Senegalese sole (Solea senegalensis). Aquaculture 233, 293-304.

Bakke-McKellep, A.M., Nordrum, S., Krogdahl, A., Buddington, R.K., 2000. Absorption of glucose, amino acids and dipeptides by the intestines of Atlantic salmon (Salmo salar L.). Fish Physiol. Biochem. 22, 33-34.

Berge, G.M., Storebakken, T., 1996. Fish protein hydrolyzate in starter diets for Atlantic salmon (Salmo salar) fry. Aquaculture 145, 205-212.

Bessey, O.A., Lowry, O.H., Brock, M.J., 1946. Rapid coloric method for determination of alkaline phosphatase in five cubic millimeters of serum. J. Biol. Chem. 164, 321-329.

Bøgwald, J., Dalmot, R.A., McQueen Leifson, R., Stenberg, E., Gildberg A., 1996. The stimulatory effect of a muscle protein hydrolysate from Atlantic cod, Gadus morhua L., on Atlantic salmon, Salmo salar L., head kidney leucocytes. Fish \& Shellfish Immunology 6, 3-16.

Boza, J.J., Jiménez, J., Martínez, O., Suárez, M.D., Gil, A., 1994. Nutritional value and antigenicity of two milk protein hydrolysates in rats and guinea pigs. J. Nutr. 124, 1978- 1986.

Bradford, M.M., 1976. A rapid and sensitive method for the quantitation of microgram quantities of protein utilizing the principle of protein-dye binding. Anal. Biochem. 72, 248-254.

Cahu, C.L., Zambonino Infante, J.L., 1994. Early weaning of sea bass (Dicentrarchus labrax) larvae with a compound diet: effect on digestive enzymes. Comp. Biochem. Physiol. 109A, 213-222. 
Cahu, C.L., Zambonino Infante, J.L., 1995. Maturation of the pancreatic and intestinal digestive functions in sea bass (Dicentrarchus labrax): effect of weaning with different protein sources. Fish Physiol. Biochem. 14, 431-437.

Cahu C.L, Zambonino Infante, J.L., Quazuguel, P., Le Gall, M.M., 1999. Protein hydrolysate vs. fish meal in compound diets for 10-day old sea bass Dicentrarchus labrax larvae. Aquaculture 171, 109-119.

Carvalho, A.P., Escaffre, A.M., Oliva Teles, A., Bergot, P., 1997. First feeding of common carp larvae on diets with high levels of protein hydrolysates. Aquacult. Int. 5, 361-367.

Carvalho, A.P., Oliva-Teles A., Bergot, P., 2003. A preliminary study on the molecular weight profile of soluble protein nitrogen in live food organisms for fish larvae. Aquaculture, 225, 445-449.

Carvalho, A.P., Sá, R., Oliva-Teles, A., Bergot, P., 2004. Solubility and peptide profile affect the utilization of dietary protein by common carp (Cyprinus carpio) during early larval stages. Aquaculture 234, 319-333.

Chen, X.L., 2003. Two different proteases produced by a deep-sea psychrotrophic bacterial strain, Pseudoaltermonas sp. SM9913. Mar. Biol. 143, 989-993.

Coste, M., Huneau, J.F., Mahe, S., Tomé, D., 1992. Interactions between milk protein peptides and intestinal mucosa. In: Paubert-Braquet, M., Dupont, C., Paoleti, R. (Eds.) Foods, Nutrition and Immunity, Dyn. Nutr. Res. Basel, Krager, vol. 1, pp. 96-103.

Crane, R.K., Boge, G., Rigal, A., 1979. Isolation of brush border membranes in vesicular form from the intestinal spiral valve of the small dogfish (Scyliorhinus canicula). Biochim. Biophys. Acta 554, 264-267.

Dabrowska, H., Grudniewski, C., Dabrowski, K., 1979. Artificial diets for common carp: effect of the addition of enzyme extracts. The Progressive Fish-Culturist 41, 196-200.

Dabrowski, K., 1984. The feeding of fish larvae: present 'state of the art' and perspectives. Reproduction, Nutrition et Développement 24, 807-833.

Daoud, R., Dubois, V., Bors-Dodita, L., Nedjar-Arroume, N., Krier, F., Chihib, N.E., Mary, P., Kouach., M., Briand, G., Guillochon, D., 2005. New antibacterial peptide derived from bovine hemoglobin. Peptides, 26, 713-719.

Day, O.J., Howell, B.R., Jones, D.A., 1997. The effect of dietary hydrolyzed fish protein concentrate on the survival and growth of juvenile Dover sole, Solea solea (L.), during and after weaning. Aquacult. Res. 28, 911 - 921.

Espe, M., Lied, E., 1999. Fish silage prepared from different cooked and uncooked raw materials: Chemical changes during storage at different temperatures. Journal of the Science of Food and Agriculture 79, 327-332.

Espe, M., Sveier, H., Høgøy I, Lied, E., 1999. Nutrient absorption and growth of Atlantic salmon (Salmo salar L.) fed fish protein concentrate. Aquaculture 174, 119-137.

Fagbenro, O., Jauncey, K., Haylor, G., 1994. Nutritive value of diets containing dried lactic acid fermented fish silage and soybean meal for juvenile Oreochromis niloticus and Clarias gariepinus. Aquat. Living Resour. 7, 79-85.

Felsenstein, J., 1996. Inferring phylogenies from protein sequences by parsimony, distance, and likelihood methods. In: Doolittle, R.F. (Ed.), Computer Methods for Macromolecular Sequence Analysis. Methods in Enzymology, vol. 266. Academic Press, Orlando, FL, pp. 418- 427. 
Felske, A.D., Heyrman, J., Balcaen, A., de Vos, P., 2003. Multiplex PCR screening of soil isolates for novel Bacillus-related lineages. J. Microbiol. Methods 55, 447-458.

Folch, J., Lees, M., Sloane-Stanley, G.H., 1957. A simple method for the isolation and purification of total lipids from animal tissues. J. Biol. Chem. 226, 497-509.

Gatesoupe, F.J., 1995. A method for the early assessment of the quality of turbot larvae. Aquacult. Int. 3, 150-154.

Gatesoupe, F.J., 1997. Siderophore production and probiotic effect of Vibrio sp. associated with turbot larvae, Scophthalmus maximus. Aquatic Living Resour. 10, 239-246.

Gatesoupe F.J., 2002. Probiotic and formaldehyde treatments of Artemia nauplii as food for larval pollack, Pollachius pollachius. Aquaculture 212, 347-360.

Gatesoupe, F.J., Zambonino Infante, J.L., Cahu C., Quazuguel, P., 1997. Early weaning of sea bass larvae, Dicentrarchus labrax: the effect on microbiota, with particular attention to iron supply and exoenzymes. Aquaculture 158, 117-127.

Gildberg, A, Bøgwald, J., Johansen, A., Stenverg, E., 1996. Isolation of acid peptide fractions from a fish protein hydrolysate with strong stimulatory effect on Atlantic salmon (Salmo salar) head kidney leucocytes. Comp. Biochem. Physiol. 114B, 97-101.

Govoni, J.J., Boehlert, G.W. and Watanabe, Y., 1986. The physiology of digestion in fish larvae. Environmental Biology of Fishes 16, 59-77.

Grisez, L., Reyniers, J., Verdonck, L., Swings, J., Ollevier, F., 1997. Dominant intestinal microflora of sea bream and sea bass larvae, from two hatcheries, during larval development. Aquaculture 155, 387-399.

Hardy, R.W., 1991. Fish hydrolysates: production and use in aquaculture feeds. In: Akiyama, D.M., Tan, R.K.H. (Eds.), Proc. Aquaculture Feed Processing and Nutrition Workshop. American Soybean Association, Singapore, pp. 109-115.

Heras, H., McLeod, C.A., Ackman, R.G., 1994. Atlantic dogfish silage vs. herring silage in diets for Atlantic salmon (Salmo salar): growth and sensory evaluation of fillets. Aquaculture 125, 93-106.

Hertrampf, J.W., Piedad-Pascual, F., 2000. Handbook on Ingredients for Aquaculture Feeds. Kluwer Academic, Dordrecht, The Netherlands, 573 pp.

Heyrman, J., Swings, J., 2001. 16S rDNA sequence analysis of bacterial isolates from biodeteriorated mural paintings in the Servilia tomb (Necropolis of carmona, Seville, Spain). Syst. Appl. Microbiol. 24, 417-422.

Hold, G.L., Pryde, S.E., Russell, V.J., Furrie, E., Flint, H.J., 2002. Assessment of microbial diversity in human colonic samples by 16S rDNA sequence analysis. FEMS Microbiology Ecology 39, 33-39.

Holm, H., Hanssen, L.E., Krogdahl, A., Florholmen, J., 1988. High and low inhibitor soybean meals affect human duodenal proteinase activity differently: in vivo comparison with bovine serum albumin. J. Nutr. 118, 515-520.

Irianto, A., Austin, B., 2002. Use of probiotics to control furunculosis in rainbow trout, Oncorhynchus mykiss (Walbaum). Journal of Fish Diseases 25, 333-342.

Kolkovski, S., Tandler, A., 2000. The use of squid protein hydrolysate as a protein source in microdiets for gilthead seabream Sparus aurata larvae. Aquacult. Nutr. 6, 11-17.

Lall, S.P., 1991. Nutritional value of fish silage in salmonid diets. Bull. Aquacult. Assoc. Can. 91, 63-74. 
Lapie, L.P., Biqueras-Benitez, C.M., 1992. Feeding studies on tilapia (Oreochromis sp.) using fish silage. FAO-Fish. Rep. 470, 165-177.

Liang, M., Wang, J., Chang, Q., Mai, K., 2006. Effects of different levels of fish protein hydrolysate in the diet on the nonspecific immunity of Japanese sea bass, Lateolabrax japonicus (Cuvieret Valenciennes, 1928). Aquacult. Res. 37, $102-106$.

Maroux, S., Louvard, D., Baratti, J., 1973. The aminopeptidase from hog-intestinal brush border. Biochim. Biophys. Acta 321, 282-295.

Métais, P., Bieth, J., 1968. Détermination de l' $\alpha$-amylase par une microtechnique. Ann. Biol. Clin. 26, 133-142.

Murray, A.L., Pascho, R.J., Alcorn, S.W., Fairgrieve, W.T., Shearer, K.D., Roley, D., 2003. Effects of various feed supplements containing fish protein hydrolysate or fish processing by-products on the innate immune functions of juvenile coho salmon (Oncorhynchus kisutch). Aquaculture 220, 643-653.

Parrish, C.C., Li, H., Indrasena, W.M., Ackman, R.G., 1991. Silage feeds in Atlantic salmon farming: flavour volatiles and lipid composition, feeding trials, and taste panels. Bull. Aquacult. Assoc. Can. 91 1, 75-84.

Patel, P., Callow, M.E., Joint, I., Callow, J.A., 2003. Specificity in the settlement modifying response of bacteria biofilms towards zoospores of the marine alga Enteromorpha. Environ. Microbiol. 5, 338-349.

Plakas, S.M., Katayama, T., 1981. Apparent digestibilities of amino acids from three regions of the gastrointestinal tract of carp (Cyprinus carpio) after ingestion of a protein and a corresponding free amino acid diet. Aquaculture 24, 309-314.

Popovic, N.T., Skukan, A.B., Strunjak-Perovic, I., Coz-Rakovac, R., Hacmanjek, M., Hunjak, B., 2004. Comparison of the API 20E and BBL Crystal E/NF identification systems for differentiating bacterial isolates from apparently healthy reared sea bass (Dicentrarchus labrax). Veterinary Research Communications 28, 93-101.

Raa J., Gildberg A., 1982. Fish silage: a review. CRC Crit. Rev. Food Sci. Nutr. 16, 383-419.

Refstie, S., Olli, J.J. Standal, H., 2004. Feed intake, growth, and protein utilisation by post-smolt Atlantic salmon (Salmon salar) in response to graded levels of fish protein hydrolysate in the diet. Aquaculture 239, 331-349.

Romanenko, L.A., Uchino, M., Mikhailov, V.V., Zhukova, N.V., Uchimura, T., 2003. Marinomonas primoryensis sp. nov., a novel psychrophile isolated from coastal sea-ice in the Sea of Japan. Int. J. Syst. Evol. Microbiol. 53, 829-832.

Rønnestad, I., Conceição, L.E.C., Aragão, C., Dinis, M.T., 2000. Free amino acids are absorbed faster and assimilated more efficiently than protein in postlarval Senegal sole (Solea senegalensis). J. Nutr. 130, 2809-2812.

Rønnestad, I., Thorsen, A., Finn, R.N., 1999. Fish larval nutrition: a review of recent advances in the roles of amino acids. Aquaculture 177, 201-216.

Rønnestad, I., Tonheim, S.K., Fyhn, H.J., Rojas-García, C.R., Kamisaka, Y., Koven, W., Finn, R.N., Terjesen, B.F., Barr, Y., Conceição, L.E.C, 2003. The supply of amino acids during early feeding stages of marine fish larvae: a review of recent findings. Aquaculture 227, 147-164.

Solano, F., Sanchez-Amat, A., 1999. Studies on the phylogenetic relationships of melanogenic marine bacteria: proposal of Marinomonas mediterranea sp. nov. Int. J. Syst. Bacteriol. 49, 1241-1246.

Szlaminska, M., Escaffre, A.M., Charlon, N., Bergot, P., 1991. Preliminary data on semisynthetic diets for goldfish (Carassius auratus L.) larvae. In: Kaushik, 
S.J., Luquet, P. (Eds.), Fish Nutrition in Practice. Biarritz, France, 24-27 June 1991. INRA, Paris, Les Colloques, 61, pp. 607-612.

Thompson, F.L., Hoste, B., Thompson, C.C., Goris, J., Gomez-Gil, B., Huys, L., De Vos, P., Swings, J., 2002. Enterovibrio norvegicus gen. nov., sp. nov., isolated from the gut of turbot (Scophthalmus maximus) larvae: a new member of the family Vibrionaceae. Int. J. Syst. Evol. Microbiol. 52, 2015-2022.

Tonheim, S.K., Espe, M., Hamre, K., Rønnestad, I., 2005. Pre-hydrolysis improves utilisation of dietary protein in the larval teleost Atlantic halibut (Hippoglossus hippoglossus L.). J. Exp. Mar. Biol. Ecol. 321, 19-34.

Watanabe, T., Kiron, V., 1994. Prospects in larval fish dietetics. Aquaculture 124, 223-251.

Zambonino Infante, J.L., Cahu, C.L., Péres, A., 1997. Partial substitution of di- and tripeptides for native proteins in sea bass diet improves Dicentrarchus labrax larval development. J. Nutr. 127, 608-614.

Zar, J.H., 1996. Biostatistical analysis. $3^{\text {rd }}$ ed., Prentice Hall, Upper Saddle River, NJ. 


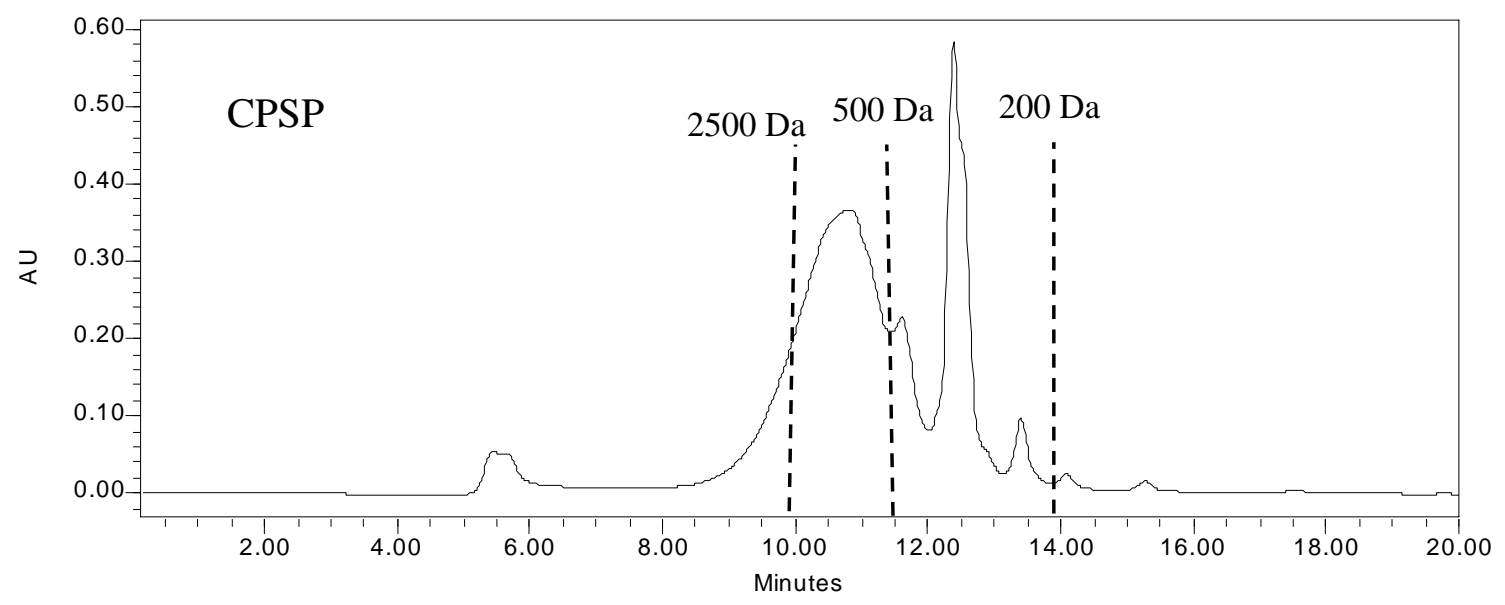

Retention time

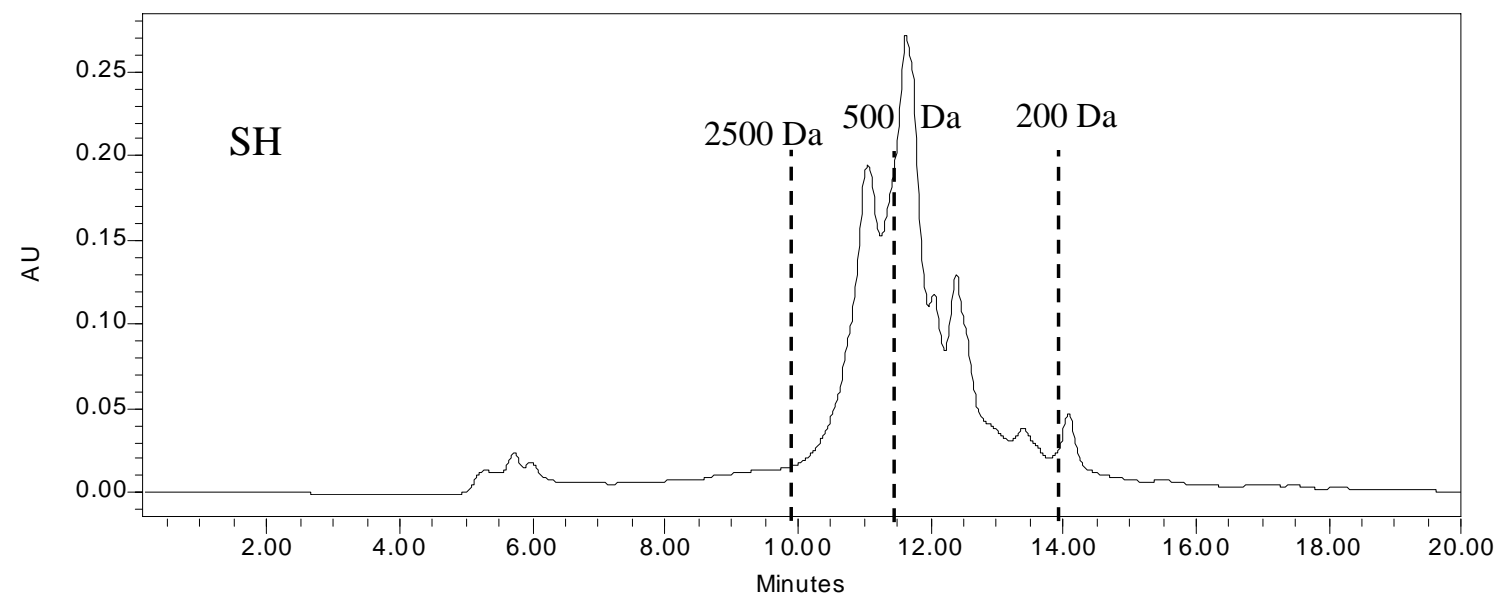

Retention time

Figure 1. Molecular weight chromatographic distribution of soluble protein nitrogen in different dietary hydrolysates (dotted vertical lines define the different fractions). 


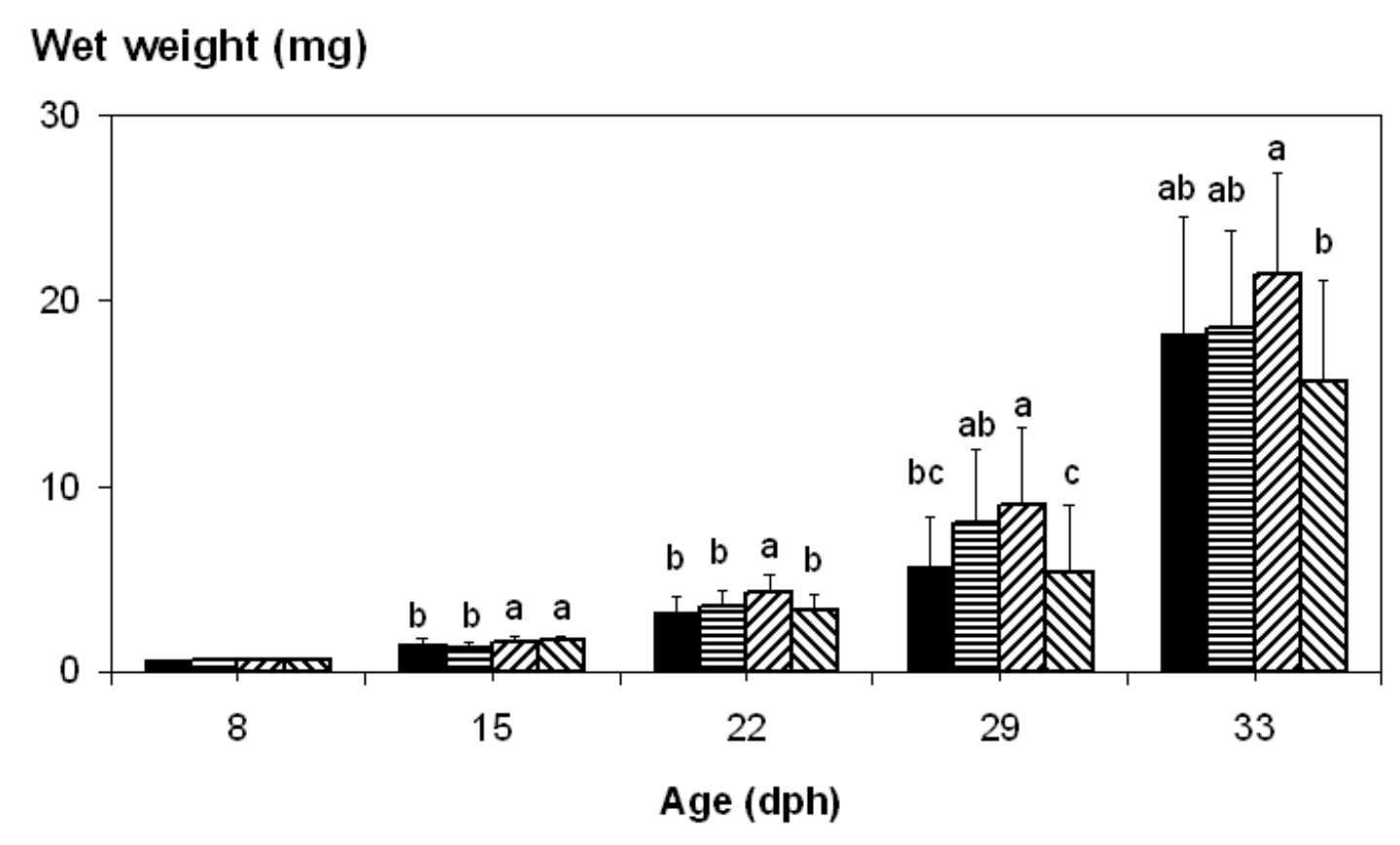

\section{口C19 目S19 $\mathbb{Q}$ C10 $\mathbb{8} S 10$}

Figure 2. Growth of sea bass larvae fed on the experimental compound diets from D8 to D33. Means \pm S.D. (n=30) with different superscript letter are significantly different $(P<0.05)$. 


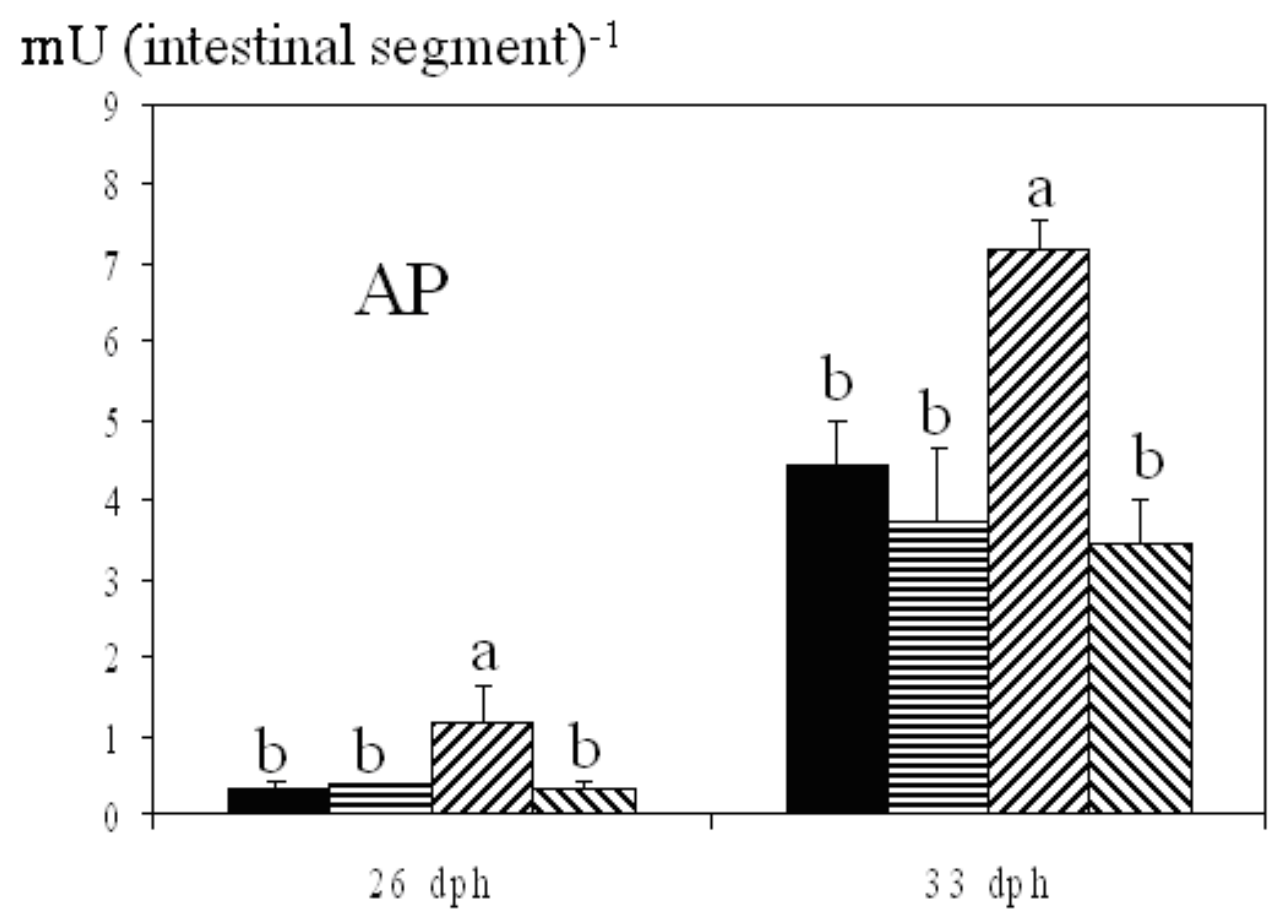

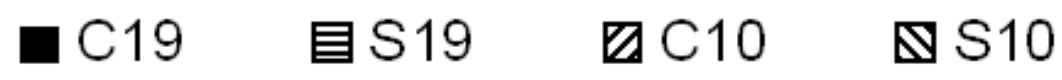

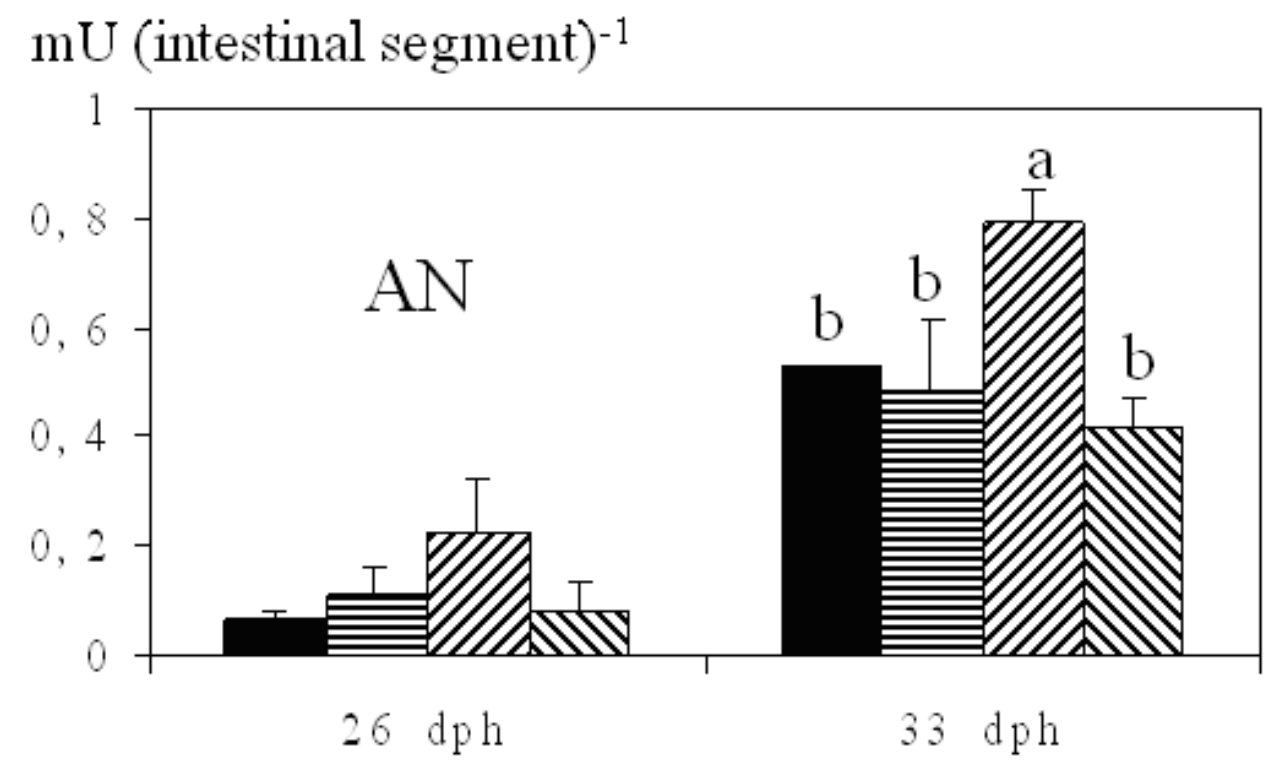

Figure 3. Segmental activities of Alkaline Phosphatase (AP) and Leucine AminoPeptidase (AN) in the intestine of larvae fed the different dietary treatments at 26 and $33 \mathrm{dph}$. Means \pm S.D. $(n=3)$ with different superscripts for significantly different activities $(P<0.05)$. 
Table 1. Ingredients and chemical composition of the experimental diets $\left(\mathrm{g} \mathrm{kg}^{-1}\right.$, on a dry matter basis)

\begin{tabular}{|c|c|c|c|c|}
\hline & C19 & S19 & $\mathrm{C} 10$ & S10 \\
\hline \multicolumn{5}{|l|}{ Ingredients } \\
\hline Fishmeal $^{\mathrm{a}}$ & 530 & 530 & 620 & 620 \\
\hline $\mathrm{CPSP}^{\mathrm{b}}$ & 190 & & 100 & \\
\hline Sardine silage & & 190 & & 100 \\
\hline Soy lecithinc & 150 & 150 & 150 & 150 \\
\hline Vitamin mix ${ }^{\mathrm{d}}$ & 80 & 80 & 80 & 80 \\
\hline Mineral mix ${ }^{\mathrm{d}}$ & 40 & 40 & 40 & 40 \\
\hline Betaine $^{e}$ & 10 & 10 & 10 & 10 \\
\hline \multicolumn{5}{|l|}{$\begin{array}{l}\text { Chemical composition } \\
\left(g \mathrm{~kg}^{-1}\right)\end{array}$} \\
\hline Dry mater & 932 & 928 & 917 & 929 \\
\hline Protein $(\mathrm{N} \times 6.25)$ & 562 & 477 & 553 & 516 \\
\hline Lipid & 160 & 214 & 170 & 195 \\
\hline Ash & 141 & 161 & 143 & 153 \\
\hline Gross energy $\left(\mathrm{J} \mathrm{kg}^{-1}\right)^{\mathrm{f}}$ & 15 & 16 & 16 & 16 \\
\hline
\end{tabular}

${ }^{a}$ Fishmeal (Norse-LT 94) supplied by La Lorientaise, Lorient, France; ${ }^{b}$ Sopropêche, Boulogne sur

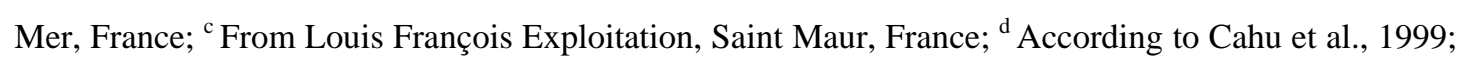

${ }^{\mathrm{e}}$ Betaine hydrochloride (99\%) from Sigma; ${ }^{\mathrm{f}}$ Calculated as: fat $\times 37.7 \mathrm{~J} \mathrm{~kg}^{-1}$; protein $\times 16.7 \mathrm{~J} \mathrm{~kg}^{-1}$. 
Table 2. Protein solubility and peptide molecular weight distribution (\%) of dietary hydrolysates. Data are the means \pm SD of two replicates. Different letters above means within each column indicate statistically significant differences $(P<0.05)$

\begin{tabular}{|c|c|c|c|c|c|}
\hline & DH (\%) ${ }^{*}$ & $<200 \mathrm{Da}$ & 200-500 Da & 500-2500 Da & $>2500 \mathrm{Da}$ \\
\hline CPSP & $61.4 \pm 2.7^{\mathrm{a}}$ & $1.5 \pm 0.5^{\mathrm{a}}$ & $36.5 \pm 0.6^{\mathrm{a}}$ & $51.4 \pm 1.2^{\mathrm{a}}$ & $10.6 \pm 1.4^{\mathrm{a}}$ \\
\hline SH & $46.5 \pm 2.8^{b}$ & $4.3 \pm 0.4^{b}$ & $54.0 \pm 0.8^{b}$ & $35.2 \pm 1.5^{b}$ & $6.5 \pm 1.1^{b}$ \\
\hline
\end{tabular}

*Degree of hydrolysis 
Table 3. Trypsin and amylase secretion (\% of activities in the intestinal segment, related to the total activity, pancreatic plus intestinal segment) per larvae at 26 and $33 \mathrm{dph}$. The means $\pm S D(n=3)$ were not significantly different $(P>0.05)$

\begin{tabular}{lcccc}
\hline & C19 & S19 & C10 & S10 \\
\hline $\begin{array}{lccc}\text { Day 26 } \\
\text { Trypsin }\end{array}$ & & & & \\
Amylase & $68 \pm 7$ & $50 \pm 3$ & $53 \pm 8$ & $43 \pm 6$ \\
& & $73 \pm 2$ & $64 \pm 10$ & $78 \pm 4$ \\
Day 33 & $58 \pm 6$ & $39 \pm 3$ & $56 \pm 4$ & $52 \pm 10$ \\
Trypsin & $68 \pm 8$ & $77 \pm 16$ & $78 \pm 2$ & $74 \pm 8$ \\
Amylase & & & \\
& & & & \\
\hline
\end{tabular}


Table 4. Bacterial counts in larvae sampled at 17 and $26 \mathrm{dph}$, in $\log \left(\mathrm{CFU} \operatorname{larva}^{-1}\right)$, means \pm S.D. $(n=3)$. The differences were not significant in a 3-way ANOVA, except for the effect of date on TCBS counts (superscripts ${ }^{a}$ and ${ }^{b}, P=\mathbf{0 . 0 4}$ ). The interactions were not significant

\begin{tabular}{llll}
\hline C19 & S19 & C10 & S10 \\
\hline
\end{tabular}

Day 17

$\begin{array}{lllll}\text { Petrifilm } & 3.6 \pm 0.7 & 3.6 \pm 0.3 & 3.7 \pm 0.7 & 3.5 \pm 0.5 \\ \text { TCBS }^{\mathrm{a}} & 2.9 \pm 0.7 & 3.2 \pm 0.4 & 2.4 \pm 0.4 & 3.2 \pm 0.3\end{array}$

Day 26

$\begin{array}{lllll}\text { Petrifilm } & 3.1 \pm 1.3 & 3.6 \pm 1.5 & 2.1 \pm 0.7 & 3.2 \pm 0.3 \\ \text { TCBS }^{\mathrm{b}} & 1.9 \pm 0.6 & 1.7 \pm 3 & 1.2 \pm 1.1 & 1.7 \pm 1.5\end{array}$


Table 5. Proportions of dominant microbiota strains in larvae sampled at $17 \mathrm{dph}(\%)$. The identification was based on alignment with nucleotide sequences currently available in NCBI database. Items referred as "others" corresponded to diverse genotypes observed only once.

\begin{tabular}{|c|c|c|c|c|c|c|}
\hline & C19 & S19 & $\mathrm{C} 10$ & S10 & Accession \#* & Alignment** \\
\hline \multicolumn{7}{|l|}{ Vibrio spp. } \\
\hline Cluster TYH3 & 7 & 39 & 0 & 19 & AY539782 & $33-634$ \\
\hline Cluster B4Y78 & 0 & 13 & 0 & 13 & AJ437193 & $18-805$ \\
\hline Others & 20 & 0 & 4 & 0 & & \\
\hline \multicolumn{7}{|l|}{ Marinomonas spp. } \\
\hline Cluster B4N46 & 0 & 0 & 35 & 0 & AJ630652*** & $1-518$ \\
\hline Cluster B4C03 & 0 & 5 & 27 & 6 & AY539835 & $30-587$ \\
\hline \multicolumn{7}{|l|}{ Bacillus spp. } \\
\hline Cluster B4C54 & 20 & 0 & 0 & 0 & AB118223 & $29-790$ \\
\hline Cluster B4C57 & 20 & 0 & 0 & 0 & AY043085 & $11-689$ \\
\hline Pseudoalteromonas sp. & 7 & 32 & 31 & 38 & AY305857 & $1429-686$ \\
\hline Others & 26 & 11 & 3 & 24 & & \\
\hline
\end{tabular}

* Accession number of a homologous partial fragment; ** position of the first and the last nucleotides corresponding to the fragment in the referenced sequence;*** new sequence, submitted for this study to EMBL. 
Table 6. Mortality (\%) of sea bass larvae fed on the experimental diets until $16 \mathrm{dph}$, then challenged for 3 days with Vibrio anguillarum. Means \pm S.E. ( $n=10$ for the challenge, $n=3$ for the control without pathogen) with different superscripts for significantly different means $(P<0.05)$. The interaction between hydrolysate and dose was not significant in the 2-way ANOVA

\begin{tabular}{|c|c|c|c|c|}
\hline Challenge & Dose 19 & Dose 10 & \multicolumn{2}{|c|}{ Hydrolysate effect $(P=0.004)$} \\
\hline CPSP hydrolysate & $19 \pm 3^{\mathrm{a}}$ & $23 \pm 5^{b}$ & & $21 \pm 2^{a}$ \\
\hline SH hydrolysate & $9 \pm 2^{b}$ & $14 \pm 2^{\mathrm{ab}}$ & & $11 \pm 2^{b}$ \\
\hline Dose effect (n.s.) & $14 \pm 2$ & $18 \pm 2$ & & \\
\hline \multirow[t]{2}{*}{ Control } & C19 & S19 & C10 & S10 \\
\hline & $1 \pm 1$ & $1 \pm 1$ & $1 \pm 1$ & $5 \pm 4$ \\
\hline
\end{tabular}

